Boletín de la Sociedad Geológica Mexicana

VOLUMEN 61, NÚM. 1, 2009, P. 97-109

\title{
Evaluation of contribution sources for the sediments of the La Paz Lagoon, based on statistical treatment of the mineralogy of their heavy fraction and surrounding rock and drainage basin characteristics
}

\author{
Konstantin Choumiline ${ }^{1, *}$, Lucio Godínez Orta ${ }^{2, \neq}$, Natalia Nikolaeva $^{3}$, Alexander Derkachev ${ }^{3}$, \\ Evgueni Shumilin ${ }^{2, \neq}$ \\ ${ }^{1}$ Universidad Autónoma de Baja California Sur, Carretera al Sur, Km. 5.5, La Paz, Baja California Sur \\ ${ }^{2}$ Centro Interdisciplinario de Ciencias Marinas, Avenida IPN s/n, Col. Playa Palo de Santa Rita, Apdo Postal 592, La Paz, Baja \\ California Sur, 23096 \\ ${ }^{3}$ Pacific Ocean Institute of Oceanology, Russian Academy of Sciences, Vladivostok, Russia \\ ${ }^{\ddagger}$ Becario de COFAA \\ *constan_ayanami@hotmail.com
}

\begin{abstract}
To identify the main sources of terrigenous sediments of the La Paz Lagoon, a description of the hydrology of the drainage basins and the mineralogy of the heavy fraction of the lagoon sediments is needed. In this work, 14 terrigenous sediment samples from the arroyos (dry streams) and 55 superficial marine sediment samples were collected from the study area. The drainage basins of the principal arroyos discharging into the lagoon were defined using geomorphologic analyses on Geographic Information Systems (GIS). The sediment samples' grain size fraction of $3.25-3.00$ phi was obtained by sieving. The heavy minerals were separated using bromoform and the mineralogical composition was determined using a petrographic polarization microscope. Three main sedimentary provinces in the lagoon were distinguished based on principal component analysis of the heavy mineral data and the study of the surrounding regional streams. The eastern sedimentary province is characterized by the predominance of orthopyroxene, especially hypersthene, as well as a high hornblende presence. This is due to the erosion of volcanoclastic sequences of the Comondú Formation and intrusive granitic complexes of Sierra de Las Cruces. The southeastern province displays a high abundance of hornblendes (up to $81 \%$ in some stations), micas, apatite, sphene, anatase, tourmaline, chlorite, clinopyroxene and orthopyroxene. Lower contents of amphibole (up to $27.2 \%$ in some stations) and resistant garnet and zircon minerals were found, as were some soft-pink piedmontite and pale-green hypersthene. These minerals were supplied by the El Cajoncito, Los Bledales, La Palma, Cardonal and El Novillo arroyos eroding the intrusive rocks of "Granito Sierra de Las Cruces", "Tonalita La Buena Mujer" and in a smaller extent the extrusive and non-marine rocks (tuffs, riodacites, conglomerates and sandstones) of the Comondú Formation. The predominant minerals of the northwestern province are clinopyroxene, orthopyroxene and phosphatic ooids. Relatively high abundance of olivine, hornblende, zircon, epidote and garnet were also found. These minerals are presumably supplied by the arroyos La Ardilla and other streams to the north of the El Centenario and El Comitán villages, as well as by eolian and littoral transport of the El Mogote sandbar dunes, which accumulates eroded sediments from the marine sedimentary rocks of El Cien Formation.
\end{abstract}

Keywords: sediments, heavy minerals, drainage basins, La Paz Lagoon, principal component analysis, contribution sources.

\section{Resumen}

Para identificar las principales fuentes de aporte de sedimentos terrígenos hacia la Laguna de La Paz la descripción de la hidrología de las cuencas de drenaje con la mineralogía de la fracción pesada de los sedimentos de la laguna es necesaria. En este 
trabajo, 14 muestras de sedimentos terrígenos de arroyos y 55 muestras de sedimentos marinos superficiales fueron colectadas en el área de estudio. Las cuencas de drenaje de los principales arroyos que desembocan en la laguna fueron distinguidas usando análisis geomorfológicos en Sistemas de Información Geográfica (SIG). El tamaño de grano de la fracción de 3.25 - 3.00 phi de los sedimentos fue obtenida mediante tamizado. Los minerales pesados fueron separados usando bromoformo y la composición mineralógica fue determinada utilizando un microscopio petrográfico de polarización. Tres provincias sedimentarias de la laguna fueron distinguidas en base al análisis de componentes principales de datos de minerales pesados y el estudio de los arroyos de la región. La provincia sedimentaria oriental se caracteriza por la predominancia de ortopiroxeno, especialmente hiperstena, al igual que por una alta presencia de hornblenda. Esto se debe a la erosión de secuencias volcanoclásticas de la Formación Comondú y omplejos intrusivos graniticos de la Sierra de Las Cruces. La provincia suroriental muestra una alta abundancia de hornblendas (hasta 81\% en algunas estaciones), micas, apatita, esfena, anatasio, turmalina, clorita, clinopiroxeno y ortopiroxeno. Menores contenidos de anfiboles (27.2\% en algunas estaciones) y de minerales resistentes granate y zircón fueron encontradas, al igual que algunas piedmontitas de color rosa-suave e hiperstenas verde-pálidas. Estos minerales fueron suministrados por los arroyos El Cajoncito, Los Bledales, La Palma, Cardonal y El Novillo que erosionaron rocas de "Granito Sierra de Las Cruces", "Tonalita La Buena Mujer" y en menor cantidad rocas extrusivas y no-marinas de la Formación Comondú. Los minerales predominantes de la provincia noroccidental son clinopiroxenos, ortopiroxenos y ooides fosfáticos. Abundancias relativamente altas de olivino, hornblenda, zircón, epidota y granate también fueron encontradas. Los minerales mencionados fueron posiblemente traídos por los arroyos La Ardilla y otras corrientes al norte de los poblados El Centenario y El Comitán, al igual que por transporte éólico y litoral de las dunas de la barra arenosa El Mogote, que acumula sedimentos erosionados de las rocas sedimentarias marinas de la Formación el Cien.

Palabras clave: sedimentos, minerales pesados, cuencas de drenaje, Laguna de La Paz, análisis de componentes principales, fuentes de aporte.

\section{Introduction}

The effect of the terrigenous input on the composition of marine sediments has always attracted the attention of sedimentologists (Martin and Meybeck, 1979; Kennet, 1982; Salomons and Förstner, 1984; Lisitzin, 1996; Chester, 2000). Climatic conditions and the composition of rocks in the drainage basins are the principal factors that control sediment flux and distribution (Milliman, 1981; Chester, 2000). Most of the studies were conducted in temperate climatic zones, where river input is permanent. In comparison, arid coastal areas are less studied, with some exceptions (Carriquiry and Sánchez, 1999). These authors showed the existence of two different terrigenous sediment sources for the Upper Gulf of California based on the results of heavy mineral analysis. The southern part of the Baja California peninsula also experiences an arid or semiarid climate. Around the La Paz Bay, the annual rainfall is relatively low (100 mm y ${ }^{-1}$ ) (Farfán and Cortez, 2005). After the passage of tropical cyclones (typically between July and November), episodic water discharge through dry streams (arroyos) supply solid and dissolved materials to the coastal marine environment (Silverberg et al., 2007).

The area adjacent to the La Paz Lagoon, which is part of the much larger La Paz Bay, includes the junction of three geologic subprovinces (Sierra La Giganta, Llano Purisima-Iray and Region del Cabo), each with different geological settings and rock composition: sedimentary, volcanic and intrusive respectively (Hausback, 1984; Aranda-Gómez and Pérez-Venzor, 1988; Álvarez-Arellano et al., 1997; Anónimo, 1999). The dry streams transport eroded rock sediments into the lagoon during episodic high precipitation events. The sediments of this marine embayment presumably are the product of source rock erosion, in conjunction with the effects of tidal currents and wave action (Cruz-Orozco et al., 1989, 1996; Godinez-Orta et al., 1997; Rodríguez-Meza, 1999; Salinas-González, 2000; Shumilin et al., 1998, 2001).

The objective of this study is to infer the main sedimentary provinces in the La Paz Lagoon using heavy mineral distribution in bottom sediments, while coupling this information with geomorphological and lithological analyses of the drainage basins of arroyos discharging into the lagoon.

\section{Materials and methods}

\subsection{Description of the study area}

The study area is located in the southern part of the Baja California peninsula in Northwestern Mexico. The La Paz Lagoon is located to the south of the La Paz Bay and is adjacent to the north coast of La Paz city. This lagoon is receiving episodic discharges from La Ardilla, San Pedro, El Novillo, El Cardonal, La Palma, Los Bledales and El Cajoncito arroyos. These arroyos cut through volcanic and volcanoclastic rocks of the Comondú Formation (Hausback., 1984), marine rocks of the El Cien Formation (Fischer et al., 1995), intrusive basement rocks of the "Granito Sierra de Las Cruces or Tonalita La Buena Mujer” (Aranda-Gómez and Pérez-Venzor, 1988) and alluvial deposits (Figure 1). 


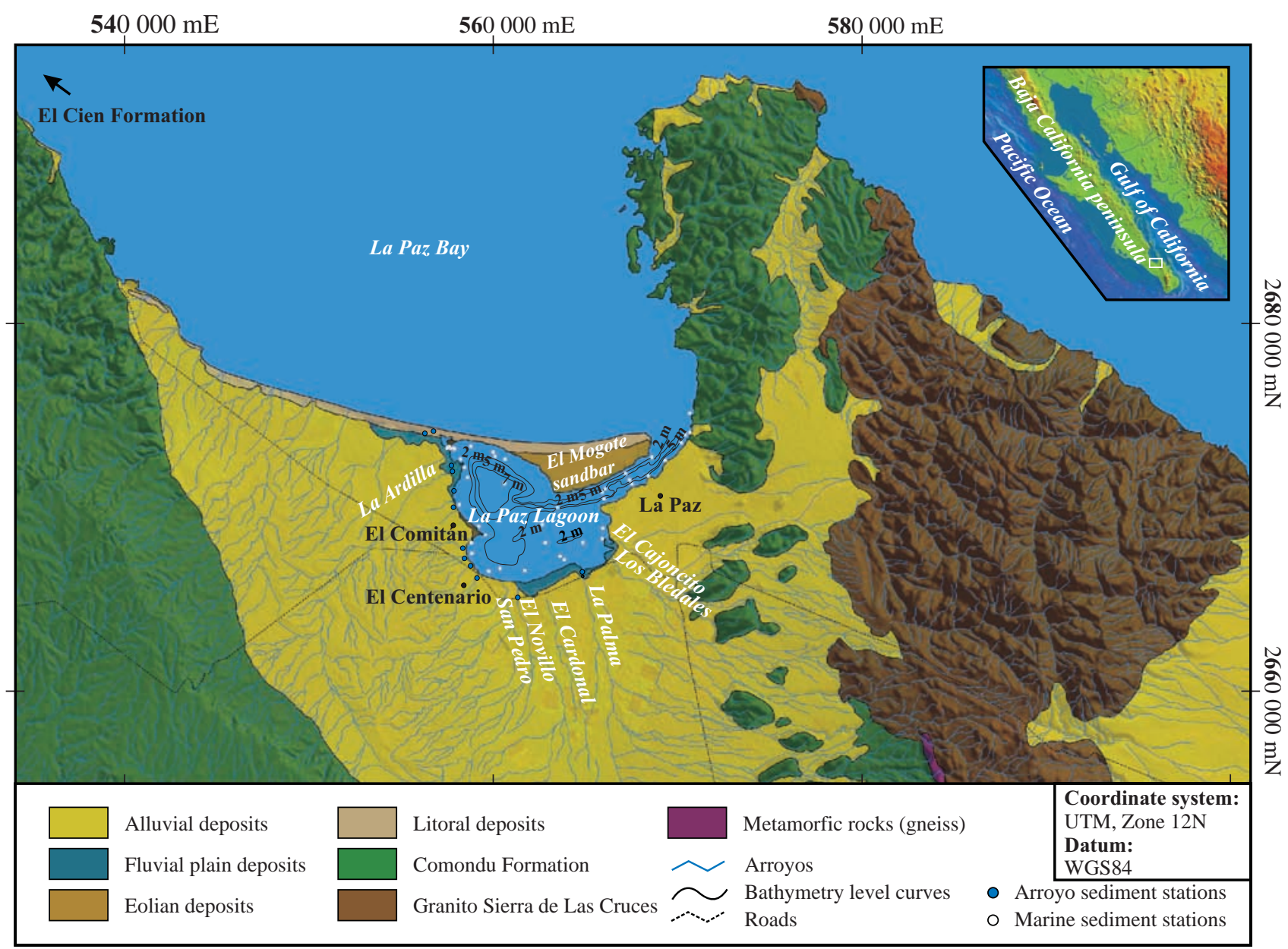

Figure 1. Location of the sampling stations, bathymetry, surrounding geology and drainage basins of the La Paz Lagoon.

\subsection{Sampling, analysis and statistical treatment of data}

To study the mineralogy of the sediments of the lagoon and the adjacent arroyos along the coastline, two series of samples were obtained in October 1996: 14 samples of sediments of the arroyos and 55 samples of marine superficial sediments (Figure 1). These samples were dried under ambient conditions and then at $60^{\circ} \mathrm{C}$ in an oven overnight. Standard sieves were then used to separate the $3.25-3.00$ phi fraction, which corresponds to very fine sand in the Wenthworth grain size classification. To separate the heavy minerals, the obtained subsamples were treated using tribromomethane (bromoform) with a density of 2.89 $\mathrm{g} \mathrm{cm}^{-3}$. The relative contribution (\%) of the heavy fraction was determined in this stage. Then, the principal constituting heavy minerals were identified with a petrographic polarization microscope in immersion liquid with a refractive index of 1.655. To identify the non-transparent minerals (ilmenite, leucoxene, hematite) a reflected light adapter was activated. The quantity of magnetite was assessed by moving a magnet under the microscope stage. In every analysis, at least 300 individual grains were counted. Heavy mineral abundance data was analyzed using STATISTICA software, including P- and Q-mode principal component analysis (PCA) with Varimax rotation, which allowed to establish the different sedimentary provinces. Surfer 8 software was used to interpolate the spatial distributions of the abundance of diverse minerals in the heavy fraction of the marine sediments. A GIS spatial analysis with Arcview 3.2 was applied to correlate the geomorphologic data of drainage basins of the arroyos, regional lithologies, and spatial distribution of representative heavy minerals in the sediments with the related sedimentary provinces in the lagoon.

\section{Results and Discussion}

\subsection{Spatial distribution of heavy fraction of sediments}

The spatial distribution of the heavy fraction (HF) of the lagoon sediments is displayed in Figure 2. The highest relative contents of HF $(10 \%-41.8 \%)$ were found near the 


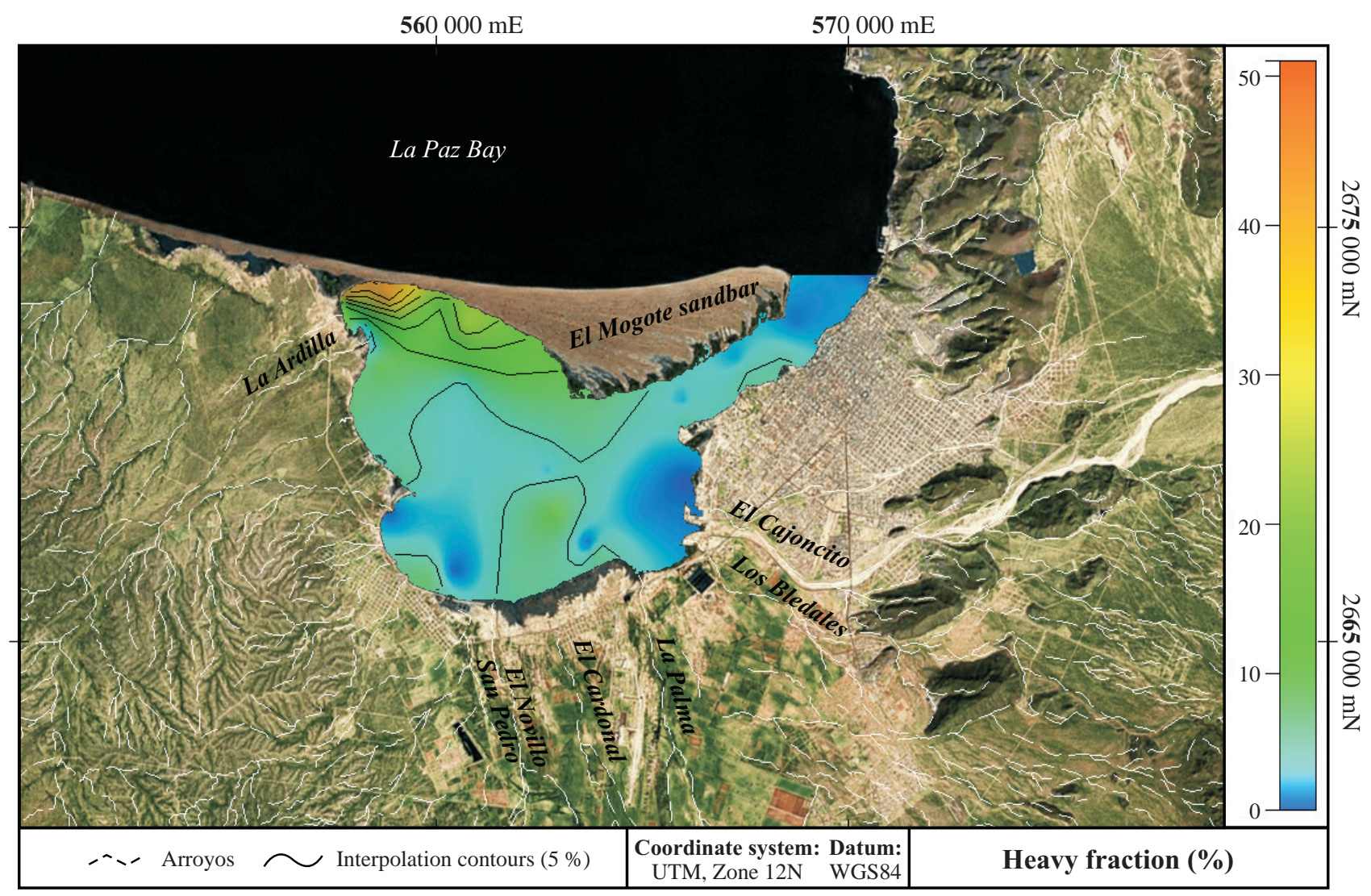

Figure 2. Spatial distribution of relative abundance of the heavy fraction in the sediments of the La Paz Lagoon.

isthmus of El Mogote sandbar. They decrease when moving away from the coast into the lagoon (5-10\%) and reach their minimum values in the sediments of the central part of this embayment (less than 5\%). Elevated abundances of HF (5-10\%) were observed in the southern part of the lagoon. The highest contents of HF are presumably due to the eolian supply of the sediments originally brought to the isthmus of El Mogote sandbar by littoral transport from the La Paz Bay, where they appeared as a result of the weathering of the surrounding rocks.

Slight enrichment of HF in the southern part of the lagoon is due to the supply of sediment from related drainage basins. The elongated HF enrichment strip in the tidal channel is controlled by the water circulation pattern in the lagoon, which is strongly affected by tidal movements (Salinas-González, 2000). This is a typical situation for most similar lagoon systems.

\subsection{Mineral composition of heavy fraction and principal mineral associations}

The full set of original data on the mineralogical composition of each sample can be given on request to the principal author. The ranges and mean contents of the studied minerals in the heavy fraction of the terrigenous and marine sediments are presented in Table 1 . The principal feature of the data is their high variability. Heavy mineral contents higher than $5 \%$ in the sediments collected in arroyos correspond to the following sequence: brown-green hornblende $(21.7 \%)>$ hematite $(15.1 \%)>$ magnetite $(13.8 \%)>$ ilmenite $(9.5 \%)>$ clinopyroxene $(8.7 \%)$ $>$ phosphatic ooids $(7.0 \%)>$ epidote group $(6.3 \%)>$ orthopyroxene (hypersthene) (5.0\%). Such enrichment of $\mathrm{HF}$ in the marine sediments is represented by the next set: brown-green hornblende $(22.1 \%)>$ clinopyroxene $(16.5$ $\%)>$ orthopyroxene (hypersthene) $(13.9 \%)>$ phosphatic ooids $(13.4 \%)>$ ilmenite $(6.8 \%)>$ epidote group $(5.9 \%)$.

A comparison of the two series shows that brown-green hornblende, ilmenite, clinopyroxene, phosphatic ooids, epidote group, and orthopyroxene were present in both terrigenous and marine sediments, while hematite and magnetite contribute less than 5\% to marine sediments.

Representative examples of the spatial distributions of some minerals or mineral groups are shown in Figure 3. Orthopyroxene is concentrated to the north of the mouth of the lagoon and in its western and eastern coastal margins. Phosphatic ooids are more abundantly accumulated in the northern margin near the El Mogote sandbar, as well as in the southern margin of the lagoon. Opaque minerals (ilmenite, magnetite, hematite and leucoxene) were found mainly in the western margin of the lagoon, in the middle of the tidal channel and to the north of the mouth of the embayment. 
Table 1. Results of the statistical treatment (mean, standard deviation, minimum and maximum) of the heavy mineral abundance in the arroyo bed sediments and marine sediments of the La Paz Lagoon.

\begin{tabular}{|c|c|c|c|c|c|c|}
\hline \multirow{2}{*}{ Mineral } & \multicolumn{3}{|c|}{ Arroyo sediments } & \multicolumn{3}{|c|}{ Marine sediments } \\
\hline & Mean & Min & Max & Mean & Min & Max \\
\hline Actinolite & $0.3 \pm 0.7$ & 0 & 2.7 & $0.4 \pm 0.8$ & 0 & 4.9 \\
\hline Anatase and rutile & $0.0 \pm 0.1$ & 0 & 0.3 & $0.1 \pm 0.1$ & 0 & 0.5 \\
\hline Apatite & $0.8 \pm 0.9$ & 0 & 2.5 & $0.7 \pm 0.7$ & 0 & 3 \\
\hline Basaltic hornblende & $1.0 \pm 0.9$ & 0 & 3 & $2.5 \pm 3.0$ & 0 & 22.2 \\
\hline Biotite & $1.1 \pm 2.1$ & 0 & 6 & $0.4 \pm 0.9$ & 0 & 3.9 \\
\hline Brown hornblende & $0.9 \pm 0.7$ & 0 & 2.7 & $1.4 \pm 0.9$ & 0 & 4.1 \\
\hline Brown opaque minerals (iron hydroxides) & $2.2 \pm 1.1$ & 0 & 4.7 & $1.6 \pm 1.4$ & 0 & 7 \\
\hline Brown-green hornblende & $21.7 \pm 26.0$ & 0.7 & 77.8 & $22.1 \pm 19.1$ & 2.2 & 62.1 \\
\hline Calcite and aragonite & $0.0 \pm 0.0$ & 0 & 0 & $0.0 \pm 0.0$ & 0 & 0.2 \\
\hline Chlorite & $0.1 \pm 0.1$ & 0 & 0.3 & $0.1 \pm 0.2$ & 0 & 1.1 \\
\hline Clinopyroxene & $8.7 \pm 8.3$ & 0.6 & 18.5 & $16.5 \pm 9.0$ & 1.4 & 39.4 \\
\hline Colorless mica & $0.0 \pm 0.1$ & 0 & 0.3 & $0.0 \pm 0.0$ & 0 & 0.2 \\
\hline Epidote group & $6.3 \pm 3.4$ & 1.4 & 13.3 & $5.9 \pm 3.0$ & 1 & 17.8 \\
\hline Garnet & $0.6 \pm 0.6$ & 0 & 1.9 & $0.6 \pm 0.5$ & 0 & 2 \\
\hline Green mica & $0.0 \pm 0.0$ & 0 & 0 & $0.0 \pm 0.1$ & 0 & 0.3 \\
\hline Hematite & $15.1 \pm 9.8$ & 2.2 & 34 & $4.9 \pm 4.1$ & 0 & 19.4 \\
\hline Ilmenite & $9.5 \pm 5.7$ & 1.7 & 20.4 & $6.8 \pm 4.3$ & 0.6 & 22 \\
\hline Leucoxene & $0.3 \pm 0.4$ & 0 & 1.1 & $0.2 \pm 0.2$ & 0 & 0.9 \\
\hline Magnetite & $13.8 \pm 12.8$ & 0 & 34.9 & $2.1 \pm 2.6$ & 0 & 12.8 \\
\hline Non-identified rock fragments & $2.6 \pm 4.0$ & 0 & 15.9 & $4.2 \pm 3.6$ & 0.5 & 21.8 \\
\hline Olivine & $0.0 \pm 0.1$ & 0 & 0 & $0.0 \pm 0.1$ & 0 & 0.3 \\
\hline Orthopyroxene (hypersthene) & $5.0 \pm 3.8$ & 0.6 & 9.7 & $13.9 \pm 8.5$ & 3 & 43.9 \\
\hline Phosphatic ooids & $7.0 \pm 8.9$ & 0.3 & 31.8 & $13.4 \pm 8.8$ & 0 & 32 \\
\hline Pyrite & $0.0 \pm 0.1$ & 0 & 0.3 & $0.0 \pm 0.0$ & 0 & 0.3 \\
\hline Sphene & $2.3 \pm 1.7$ & 0.7 & 6.3 & $1.5 \pm 1.1$ & 0 & 4.4 \\
\hline Staurolite and andalusite (metamorphic minerals) & $0.0 \pm 0.0$ & 0 & 0 & $0.0 \pm 0.0$ & 0 & 0.3 \\
\hline Tourmaline & $0.1 \pm 0.1$ & 0 & 0.3 & $0.0 \pm 0.1$ & 0 & 0.3 \\
\hline Zircon & $0.3 \pm 0.4$ & 0 & 1.7 & $0.5 \pm 0.5$ & 0 & 2.9 \\
\hline
\end{tabular}

Hornblende tends to accumulate in the southern coastal margin of the lagoon, mostly in shallow areas. The spatial distribution of this mineral is at least partially controlled by hydrodynamics, because of its low density. Resistant minerals (garnet, zircon, apatite, sphene, tourmaline, anatase and rutile) are noticeably enriched in the HF of sediments in the southern margin and the central part of the tidal channel. Epidote group minerals (epidote, zoisite, piedmontite) are mainly found in the HF of the western margin of the lagoon.

The results of the R-mode factor analysis (Bopp and Biggs, 1981) with Varimax rotation (minimum eigenvalue of 0.5 ) of the whole set of data are presented in Table 2. This mode of analysis enables associations of heavy minerals to be discerned. The main percentages of total variances are mainly controlled by four factors: Factor $1(17.4 \%)$, Factor 2 (10.7\%), Factor 3 (9.7\%) and Factor 4 (7.9\%). Factor 1 reveals the highest negative scores for phosphatic ooids and clinopyroxene, and the highest positive values for browngreen hornblende, biotite, actinolite and sphene. Factor 2 is characterized by high negative scores for hematite, magnetite, ilmenite and rutile. Factor 3 shows the highest positive scores for epidote, calcite/aragonite, non-identified rock fragments, brown hornblende and leucoxene. Factor 4 has the highest positive scores for tourmaline, apatite, sphene and zircon. Factor 1 probably corresponds to a mafic intrusive rock source. Factors 2-4 reflect igneous and metamorphic provenances. A specific feature of the Factor 3 mineral association is the presence of rock fragments and sedimentary minerals from reworked igneous and metamorphic rocks.

The Q-mode PCA makes it possible to characterize patterns of spatial distribution of mineral associations in the sediments. The results of this analysis showed different behavior for the four obtained factors with the following percentages of variance for each: Factor 1 (26.3\%), Factor $2(18.5 \%)$, Factor 3 (3.9\%) and Factor 4 (3.3\%) (Figure 4). Factor 1 is characterized by the highest positive scores from the northern to the central part of the lagoon near the El Mogote sandbar and negative scores only in the southeastern and southwestern areas (Figure 4a). This factor could be controlled by sediment transport from El Mogote sandbar by eolian activities and tidal currents. The second factor reveals the highest positive scores in the southeastern and southwestern areas of the lagoon and the highest negative scores in the northern and western sections (Figure 4b). This factor seems to be related to the sediment input by the San Pedro, El Novillo, Cardonal, La Ardilla, Los Bledales and El Cajoncito arroyos. Factor 3 shows the highest positive values in the northwestern and southwestern parts of $\mathrm{La} \mathrm{Paz}$ Lagoon and negative values in the southern and eastern parts (Figure 4c). This third factor is possibly controlled by La Ardilla and other arroyos of El Centenario and El Comitán 
$560000 \mathrm{mE}$

$570000 \mathrm{mE}$
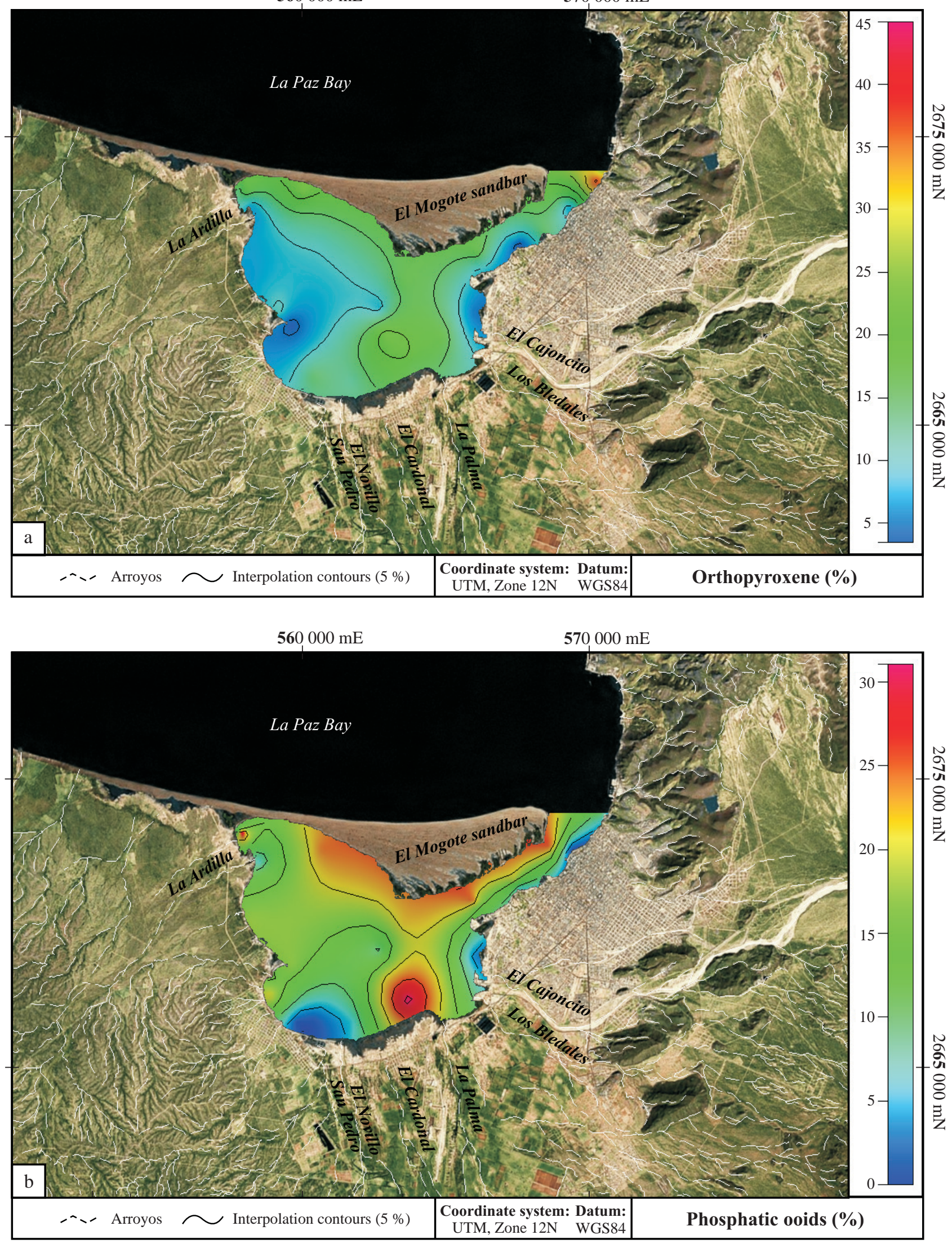

Figure 3. Spatial distributions of the relative abundance of some of the representative minerals in the HF of the sediments of the La Paz Lagoon: a) orthopyroxene; b) phosphatic ooids. 
$560000 \mathrm{mE}$

$570000 \mathrm{mE}$

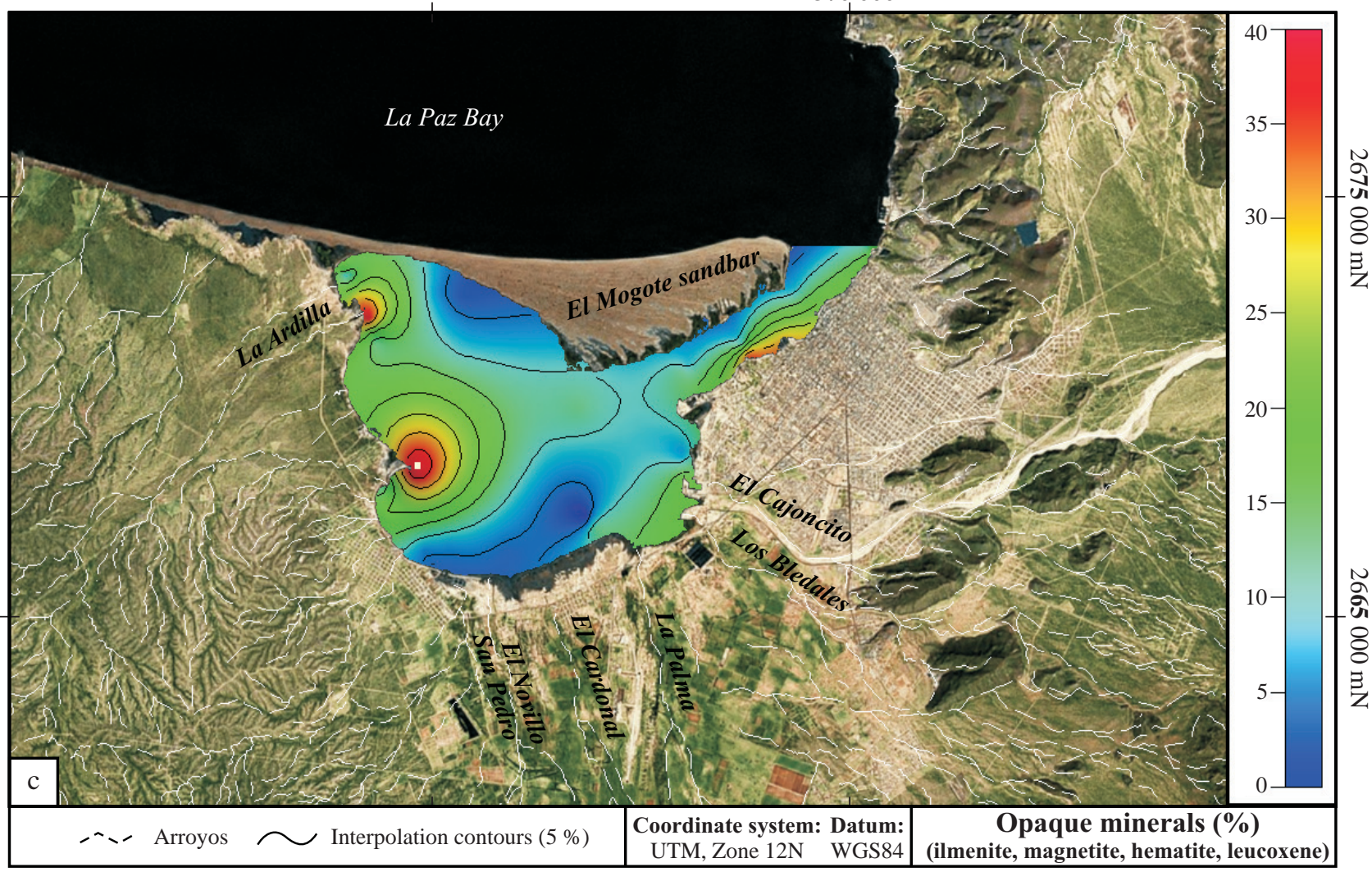

$560000 \mathrm{mE}$

$570000 \mathrm{mE}$

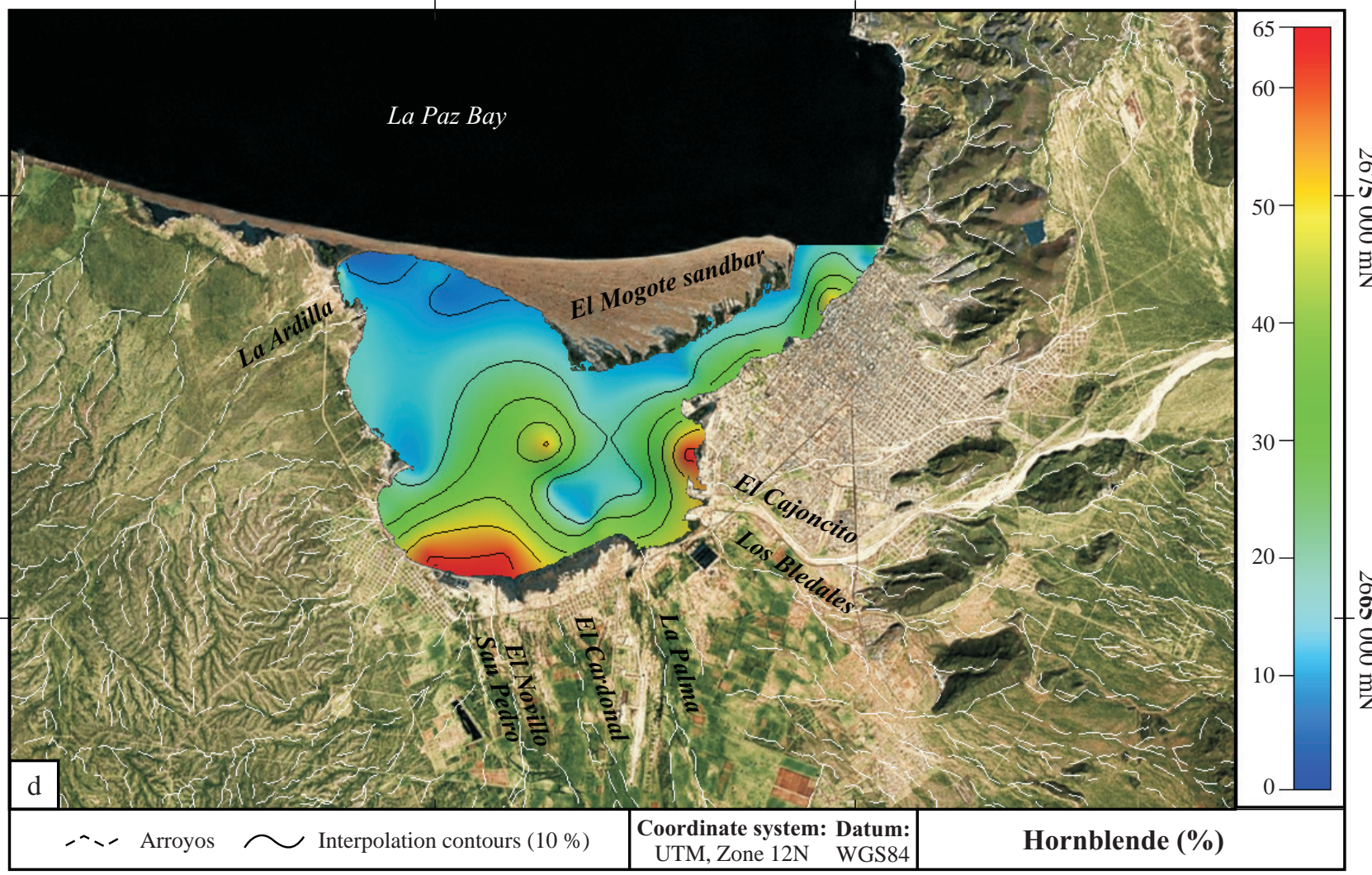

Figure 3. Spatial distributions of the relative abundance of some of the representative minerals in the HF of the sediments of the La Paz Lagoon: c) opaque minerals; d) hornblende. 
$560000 \mathrm{mE}$

$570000 \mathrm{mE}$

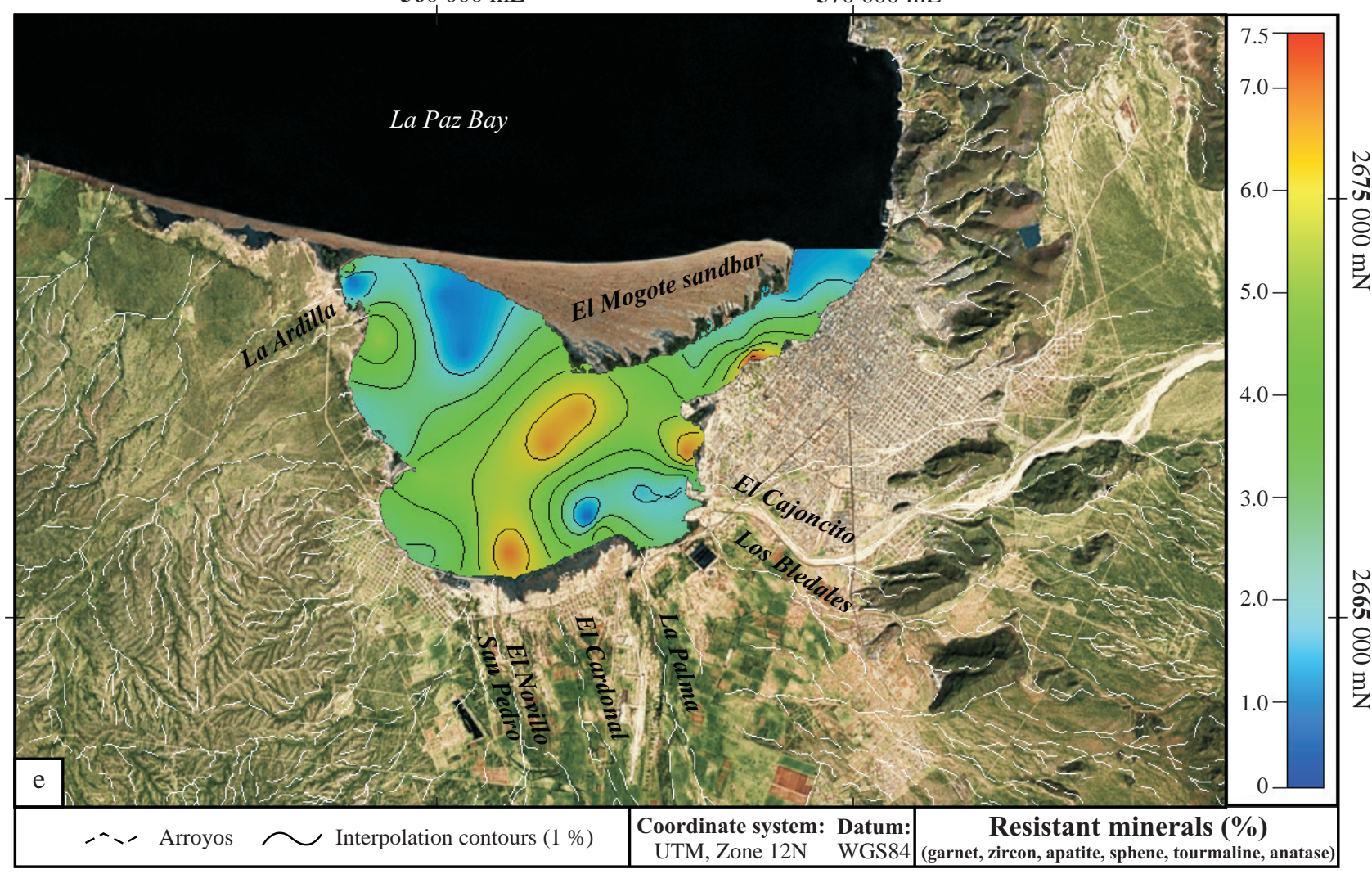

$560000 \mathrm{mE}$

$570000 \mathrm{mE}$

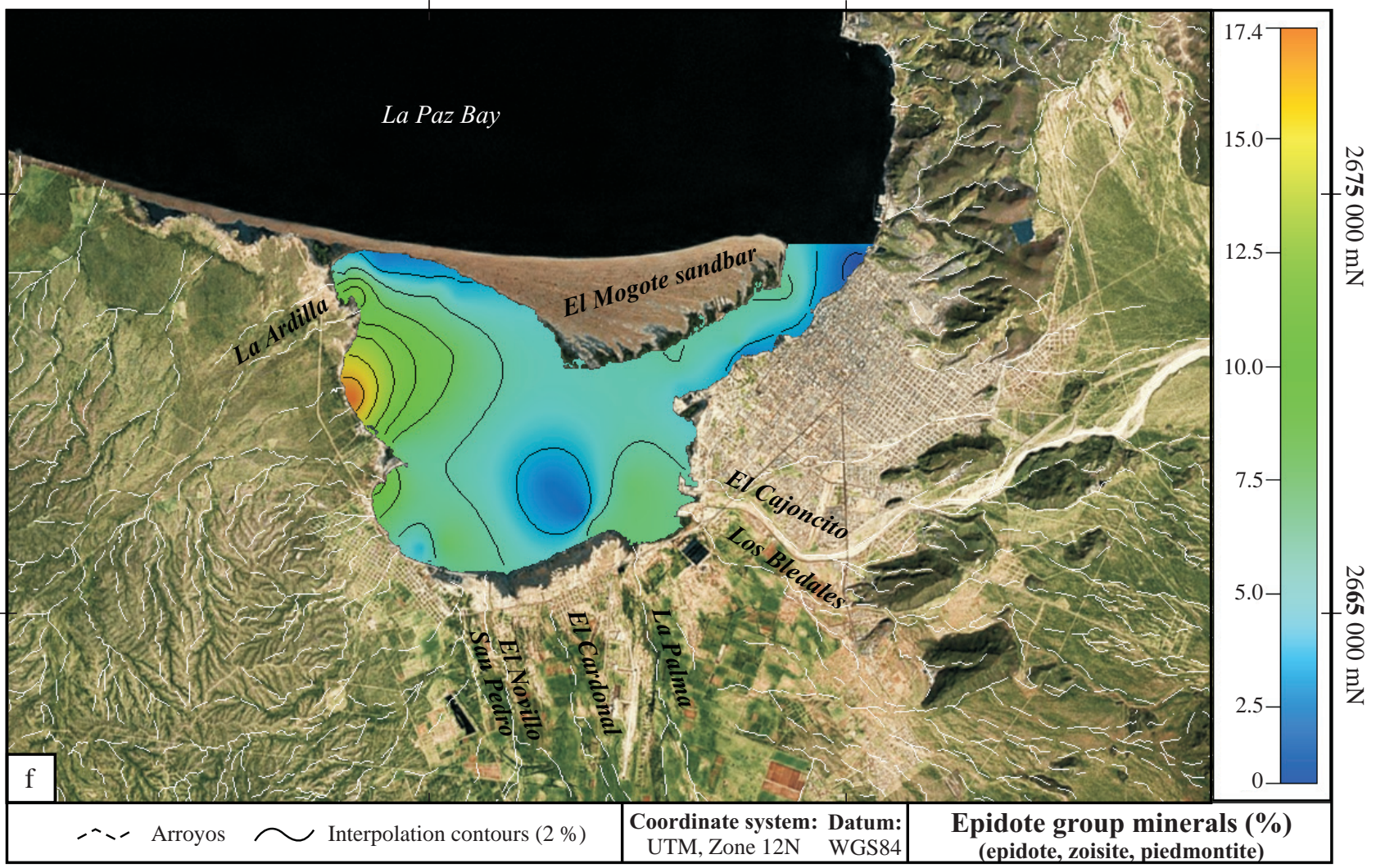

Figure 3. Spatial distributions of the relative abundance of some of the representative minerals in the HF of the sediments of the La Paz Lagoon: e) resistant minerals; f) epidote group minerals. 
Table 2. Results of the R-mode factor analysis with Varimax rotation of the data set from the mineralogical composition of the bottom sediments of the La Paz lagoon.

\begin{tabular}{|c|c|c|c|c|}
\hline Mineral & Factor 1 & Factor 2 & Factor 3 & Factor 4 \\
\hline Actinolite & 0.692612 & 0.213715 & 0.127123 & -0.102515 \\
\hline Anatase and rutile & 0.245307 & -0.508549 & 0.211295 & 0.007783 \\
\hline Apatite & 0.481688 & 0.085206 & -0.036894 & 0.556697 \\
\hline Basaltic hornblende & -0.495853 & 0.103958 & 0.149996 & 0.055276 \\
\hline Biotite & 0.743309 & 0.108121 & 0.020931 & -0.152734 \\
\hline Brown hornblende & -0.158075 & 0.317569 & 0.604766 & 0.012812 \\
\hline Brown opaque minerals (iron hydroxides) & -0.485468 & 0.104848 & 0.19402 & -0.212339 \\
\hline Brown-green hornblende & 0.908674 & 0.083693 & -0.050034 & 0.182494 \\
\hline Calcite and aragonite & -0.01986 & 0.065078 & 0.665814 & -0.006862 \\
\hline Chlorite & 0.327311 & 0.448648 & 0.060623 & 0.022047 \\
\hline Clinopyroxene & -0.792355 & 0.197885 & -0.07401 & -0.218578 \\
\hline Colorless mica & 0.264518 & -0.167446 & -0.012081 & -0.220428 \\
\hline Epidote group & 0.07903 & -0.083727 & 0.670943 & 0.172089 \\
\hline Garnet & 0.048047 & -0.31862 & 0.126664 & 0.248902 \\
\hline Green mica & -0.114016 & 0.082296 & -0.20501 & -0.080678 \\
\hline Hematite & 0.085667 & -0.826202 & 0.002123 & 0.055429 \\
\hline Ilmenite & 0.084178 & -0.640571 & 0.179042 & -0.149633 \\
\hline Leucoxene & 0.113022 & -0.187108 & 0.59431 & -0.170712 \\
\hline Magnetite & -0.106774 & -0.817046 & -0.137613 & 0.072981 \\
\hline Non-identified rock fragments & -0.074028 & 0.056705 & 0.651701 & -0.292954 \\
\hline Olivine & -0.310828 & 0.19118 & 0.107456 & 0.157473 \\
\hline Orthopyroxene (hypersthene) & -0.457731 & 0.25833 & -0.454191 & -0.431712 \\
\hline Phosphatic ooids & -0.746828 & 0.250018 & -0.023544 & 0.192401 \\
\hline Sphene & 0.516799 & -0.11948 & -0.147715 & 0.53666 \\
\hline Staurolite and andalusite (metamorphic minerals) & 0.1545 & -0.18682 & -0.173525 & -0.283375 \\
\hline Tourmaline & -0.096488 & 0.038818 & -0.155623 & 0.675857 \\
\hline Zircon & 0.094005 & -0.179896 & 0.1915 & 0.535467 \\
\hline Expl. Var. & 4.700583 & 2.888488 & 2.611965 & 2.126153 \\
\hline Prp. Totl. & 0.174096 & 0.106981 & 0.096739 & 0.078746 \\
\hline
\end{tabular}

Values in bold fonts: $>|0.5|$

villages. Factor 4 reveals the highest positive scores to the north from the mouth of the lagoon and highest negative scores near the western coast of the La Paz Lagoon (Figure 4d). This source seems to be related to littoral, eolian and wave transport of the eroded El Mogote isthmus, enriched in phosphatic grains

\subsection{Contribution sources}

The mineralogical distribution of the La Paz Lagoon could present a relationship with the surrounding rocks. Sources of marine sediments can be inferred from the mineralogy of the arroyo sediments, associated with lithologies of their drainage basins. The mineral distribution could also be controlled by lagoon water circulation or high-energy events like hurricanes that can severely alter the spatial distribution by mixing the sediments. Factors 1 and 4, defined by Q-mode factor analysis, can be spatially integrated into one mineralogical zone. The results of the factor analyses, the drainage basins of the arroyos, and the description of the surrounding lithologies allows three individual sedimentary provinces in the La Paz Lagoon sediments to be distinguished, each one with its own mineralogical association groups (Figure 5). These provinces are: east, southeast and northwest.

The eastern province is influenced by arroyos eroding volcanoclastic sequences of Comondu Formation like
"Toba Las Calaveras," "Toba El Caimancito" and "Brecha y Conglomerado Volcanicos Balandra" (Hausback, 1984; Aranda-Gómez and Pérez-Venzor, 1988), as well as an intrusive granitic complex referred as "Granito Sierra de Las Cruces" (Aranda-Gómez and Pérez-Venzor, 1988). Most of the recent alluvial deposits could have the composition of these granitic rocks.

The southeastern province is mainly affected by the sediment input from the San Pedro, El Novillo, Cardonal, La Palma, Los Bledales and El Cajoncito arroyos. The specific feature of this province is a high percentage of subangular minerals, which indicates shorter transport distance from the eroded rock. Resistant minerals like garnet, zircon, apatite, sphene, tourmaline, anatase and rutile are also enriched in this province. The mineral association corresponding to this province is probably related to the weathering of the intrusive rocks of "Granito Sierra de Las Cruces", "Tonalita La Buena Mujer" (Aranda-Gómez and Pérez-Venzor, 1988) or the extrusive and non-marine rocks (tuffs, riodacites, conglomerates and sandstones) of the Comondú Formation (Hausback, 1984; Aranda-Gómez and Pérez-Venzor, 1988).

The northwestern province is characterized by the deposition of sediments carried by La Ardilla and other arroyos to the north of the villages of El Centenario and el Comitán. The minerals comprising the sediments of this part of the lagoon probably derive from the weathering of sandstones and conglomerates to the west. A significant 

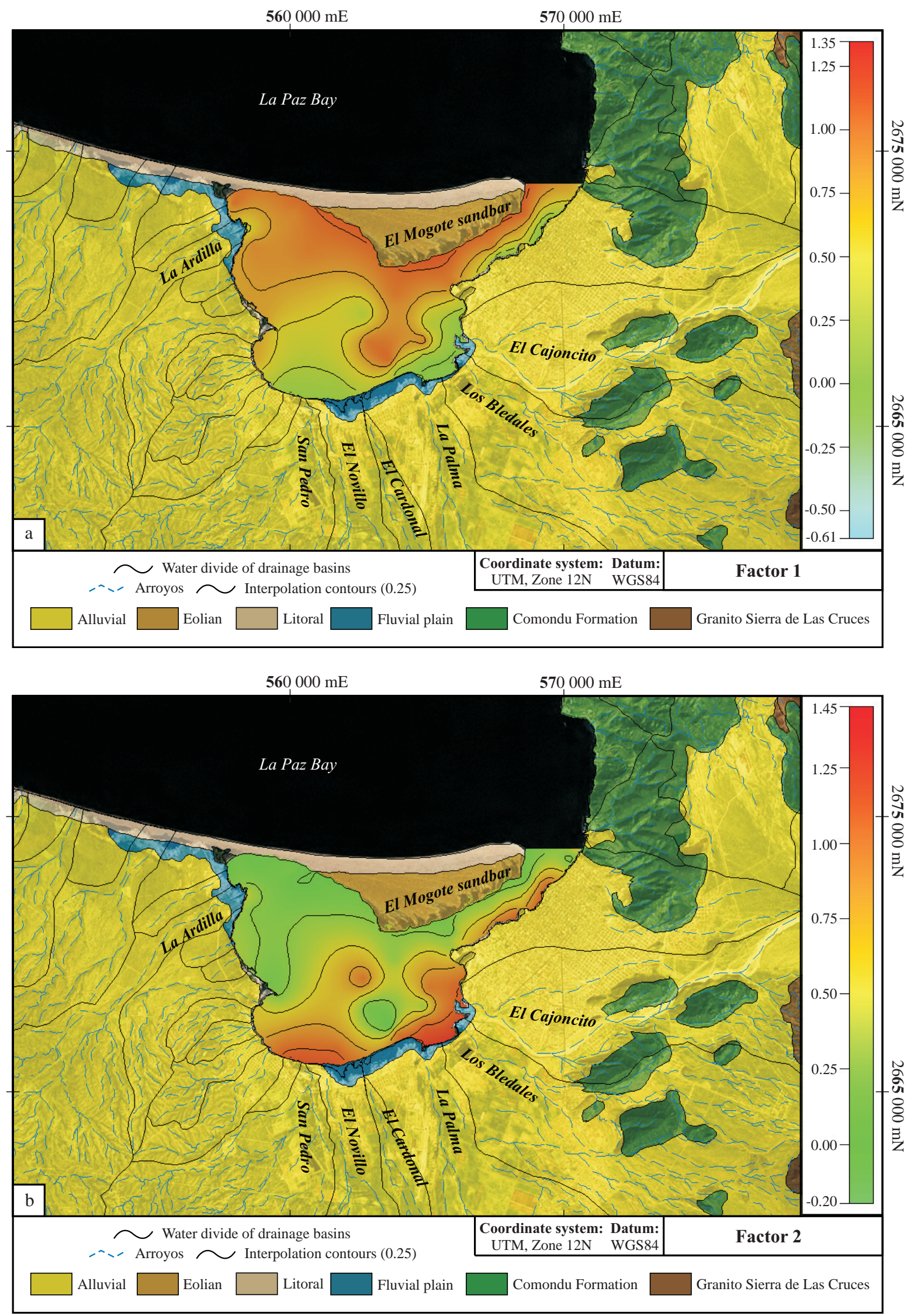

Figure 4. Spatial distribution of the principal factors controlling the distribution of heavy minerals in the sediments of the La Paz Lagoon: a) factor 1; b) factor 2 . 

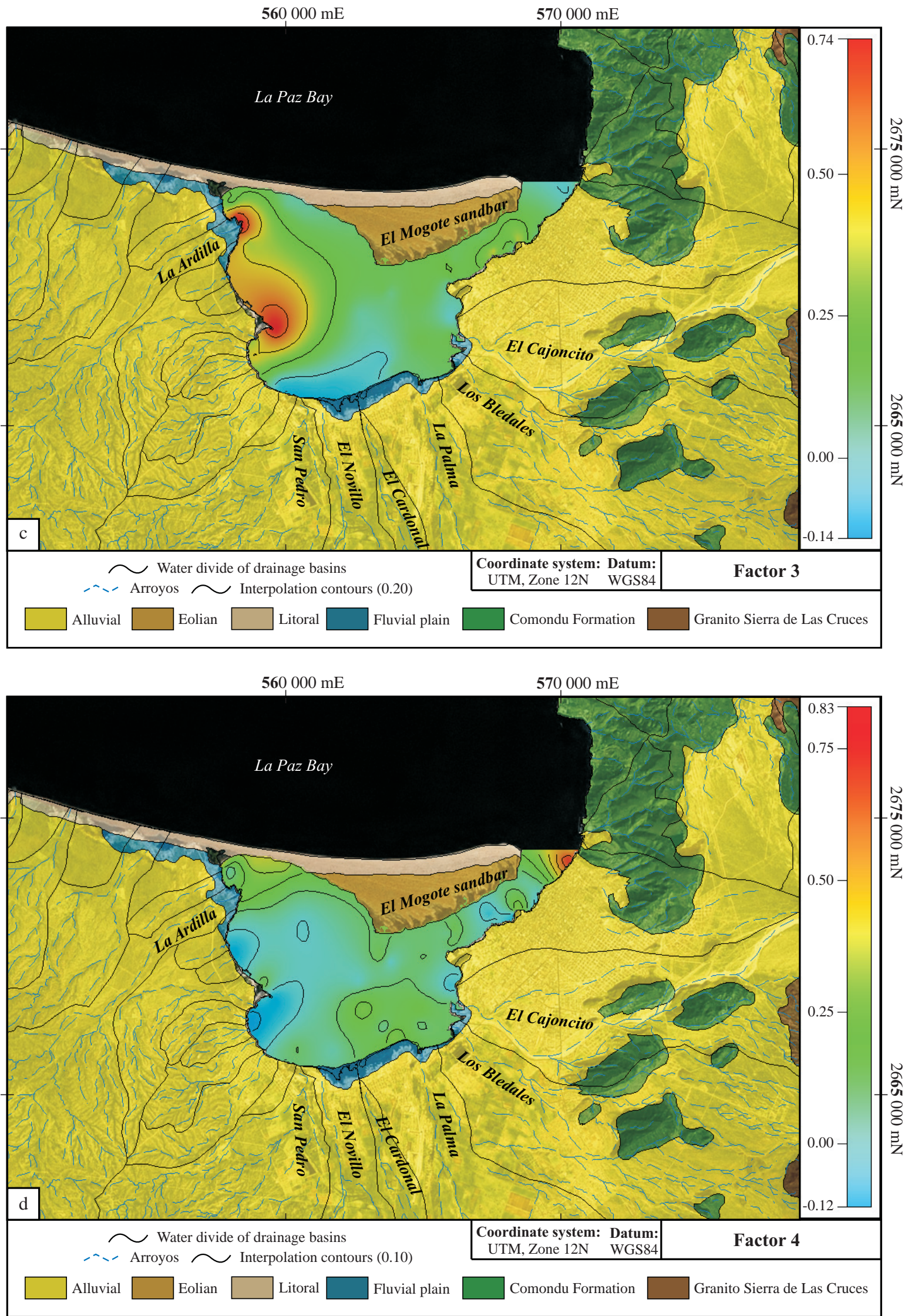

Figure 4. Spatial distribution of the principal factors controlling the distribution of heavy minerals in the sediments of the La Paz Lagoon: c) factor 3; d) factor 4 . 


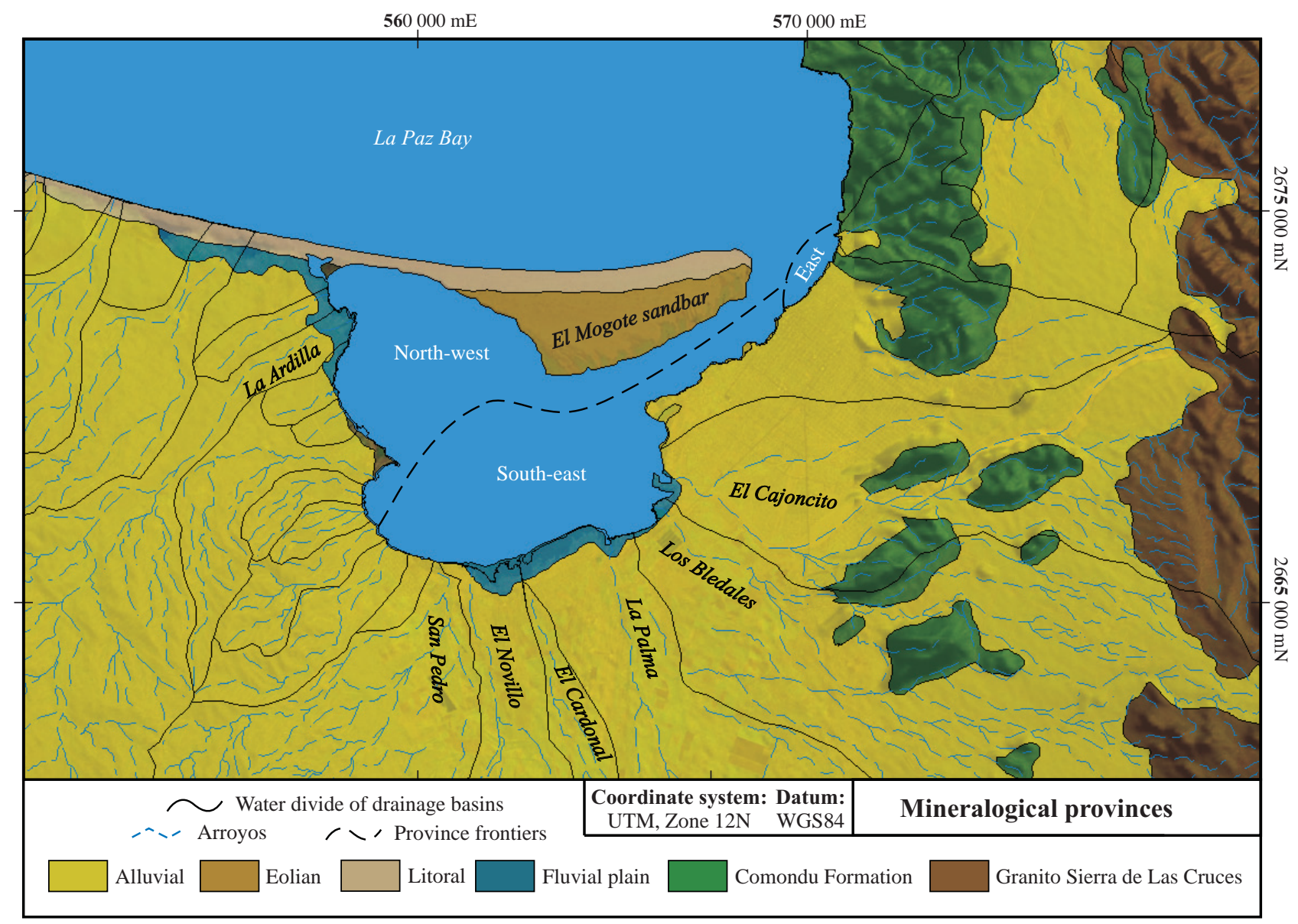

Figure 5. Arroyos, lithologies of the drainage basins and main sedimentary provinces in the sediments of the La Paz Lagoon.

number of these dry streams go through alluvial deposits that do not allow the exact source to be established because the sediments could travel long distances. The presence of phosphatic ooids could be due to the erosion of marine sedimentary rocks like the El Cien Formation (Fischer et al., 1995), which is reported to have phosphorite rock layers. The littoral, eolian and wave transport of the eroded El Mogote back beach dunes (Nava-Sánchez and Cruz-Orozco, 1989; Rodríguez-Castañeda, 2002) could also influence the mineral distribution of this province. This zone, roughly corresponding to a high abundance of HF in the sediments $(>20 \%)$ is also enriched in $\mathrm{As}, \mathrm{Cd}$ and lanthanides, which are commonly associated with phosphatic rocks (RodríguezMeza, 1999; Shumilin et al., 2001). According to the results of Rodríguez-Castañeda (2002), some element enrichments in the La Paz Bay sediments along El Mogote sandbar have natural origins, and are not caused by the phosphate mining activities of the Roca Fosfórica Mexicana Company.

\section{Conclusions}

The maximum abundance of HF (41.8\% - 10\%) was found near the isthmus of El Mogote sandbar, decreasing away from the coast (5-10\%), with minimum values in the central part of the lagoon (less than 5\%).

The principal heavy minerals with abundances higher than 5\% display the following sequences: a) browngreen hornblende $>$ hematite $>$ magnetite $>$ ilmenite $>$ clinopyroxene $>$ phosphatic ooids $>$ epidote group $>$ orthopyroxene (hypersthene) for arroyo sediments and b) brown-green hornblende $>$ clinopyroxene $>$ orthopyroxene (hypersthene) $>$ phosphatic ooids $>$ ilmenite $>$ epidote group for marine sediments. Each individual mineral has a different spatial distribution in the lagoon. Hornblende accumulates in southern shallow areas. Orthopyroxene is more frequent north of the mouth of the lagoon and in the western and eastern margins. Phosphatic ooids are more abundant in the northern margin, near the El Mogote isthmus. Opaque minerals are found in the western margin, in the middle of the tidal channel and in the La Paz Bay, near the mouth of the lagoon. Epidote group minerals prevail in the western margin of the lagoon.

Some associations of minerals were defined via the application of R-mode factor analysis. Factor 1 reveals the importance of phosphatic ooids and clinopyroxene, brown-green hornblende, biotite, actinolite and sphene. Factor 2 unifies hematite, magnetite, ilmenite and rutile. 
Factor 3 corresponds to the association of epidote, calcite/ aragonite, non-identified rock fragments, brown hornblende and leucoxene. Factor 4 associates tourmaline, apatite, sphene and zircon.

Three individual sedimentary provinces (eastern, southeastern and northwestern) can be distinguished in the La Paz Lagoon sediments based on Q-mode factor analysis. The eastern province is influenced by arroyos eroding volcanoclastic sequences of the Comondu Formation and the "Granito Sierra de Las Cruces" intrusive granitic complex. The southeastern province is defined by the inputs of arroyos to the south of the lagoon that erode intrusive complexes, as well as extrusive and non-marine rocks (tuffs, riodacites, conglomerates and sandstones) of the Comondú Formation. The northwestern province is affected by littoral, eolian and wave transport of the eroded El Mogote isthmus, enriched in phosphatic grains generated by the weathering of the El Cien Formation marine rocks.

\section{References}

Álvarez-Arellano, A.D., Rojas-Soriano, H., Prieto-Mendoza, J.J., 1997, Geología de la Bahía de La Paz y áreas adyacentes, in Urbán, J., Ramírez Rodríguez, M., (eds.), La Bahía de La Paz, Investigación y Conservación: Universidad Autónoma de Baja California Sur, Centro Interdisciplinario de Ciencias Marinas, La Paz, Mexico, 13-29.

Anónimo, 1999, Monografía geológico-minera del estado de Baja California Sur: Consejo de Recursos Minerales, Pachuca, 237 p.

Aranda-Gómez, J.J., Pérez-Venzor, J.A., 1988, Estudio Geológico de Punta Coyotes, Baja California Sur: Universidad Nacional Autónoma de México, Revista del Instituto de Geología 7, 1-21.

Bopp, F., Biggs, R.B., 1981, Metals in estuarine sediments: Factor analysis and its environmental significance: Science 214, 441-443.

Carriquiry, J.D., Sánchez, A., 1999, Sedimentation in the Colorado River Delta and Upper Gulf of California after a century of discharge loss: Marine Geology 158, 125-145.

Chester, R., 2000, Marine Geochemistry, second edition: Blackwell Science, London, $506 \mathrm{p}$.

Cruz-Orozco, R., Rojo-Garcia, P., Godinez-Orta, L., Nava-Sanchez, E.H., 1989, Topografía, hidrología y sedimentos de los márgenes de la Laguna de La Paz, B.C.S.: Revista de Investigacion Cientifica de la Universidad Autonoma de Baja California Sur 1, 3-15.

Cruz-Orozco, R., Martinez-Noriega, C., Mendoza-Maravilla, A., 1996, Batimetría y sedimentos de la Bahía de La Paz, B.C.S., México: Oceánides 11, 21-27.

Farfán, L.M., Cortez, M., 2005, An observational and modeling analysis of the landfall of hurricane Marty (2003) in Baja California, Mexico: American Meterological Society - Monthly Weather Review 133, 2060-2090.

Fischer, R., Galli-Olivier, C., Gidde, A., Schwennicke, T., 1995, The El Cien Formation of southern Baja California, Mexico: Stratigraphic precisions, Newsletters on Stratigraphy 32, 137-161.
Godínez-Orta, L., Shumilin, E., Sapozhnikov, D., Rodríguez-Meza, D., 1997, Características litológico-geoquímicas de los sedimentos superficiales de La Laguna de La Paz, B.C.S: Actas INAGEQ 3, 225-233.

Hausback, B., 1984, Cenozoic volcanic and tectonic evolution of Baja California Sur, Mexico, in Frizzell, V.A., (ed), Geology of The Baja California Peninsula: Los Angeles, Pacific Section Society of Sedimentary Geology, 219-236

Kennet, J., 1982, Marine Geology: Prentice Hall, Englewood Cliffs, USA, $813 \mathrm{p}$.

Lisitzin, A.P., 1996, Oceanic Sedimentation. Lithology and Geochemistry: Washington D.C., American Geophysical Union. 400 p.

Martin, J.M., Maybeck, M., 1979, Elemental mass balance of material carried by by major world rivers: Marine Chemistry 7, 173-206.

Milliman, J.D., 1981, Transfer of river-borne particulate material to the oceans, in Martin, J.M., Burton, J.D., Eisma, D., (eds), River Inputs to Ocean Systems: UNEP/UNESCO, Paris, 5-12.

Nava-Sánchez, E.H., Cruz-Orozco, R., 1989, Origen y evolución geomorfológica de la Laguna de La Paz, B.C.S., México: Investigaciones Marinas 4, 49-58.

Rodríguez-Castañeda, A.P., 2002, Elementos mayores y traza en sedimentos y macroalgas de la Bahía de La Paz, Baja California Sur, México: Centro Interdisciplinario de Ciencias Marinas, Instituto Politécnico Nacional, La Paz, Mexico, MSc dissertation, 120 p.

Rodríguez-Meza, G.D., 1999, Metales pesados en sedimentos de la Ensenada de La Paz, B.C.S., México: Centro Interdisciplinario de Ciencias Marinas, Instituto Politécnico Nacional, La Paz, Mexico, MSc dissertation, $130 \mathrm{p}$.

Salinas-González, F., 2000, Mezcla turbulenta y transporte de masa en la Bahía y Ensenada de La Paz, B.C.S.: Experimentación y modelación numérica: Centro Interdisciplinario de Ciencias Marinas, Instituto Politécnico Nacional, La Paz, Mexico, PhD dissertation, 260 p.

Salomons, W., Förstner, U., 1984, Metals in the hydrocycle: SpringerVerlag, Berlin, $349 \mathrm{p}$.

Shumilin, E., Green-Ruíz, C., Sapozhnikov, D., Rodríguez-Meza, D., Páez-Osuna, F., 1998, Asociaciones geoquímicas y patrones de distribución espacial de metales y metaloides en los sedimentos superficiales de la Laguna de La Paz, Baja California Sur: Actas INAGEQ 4, 23-32.

Shumilin, E., Páez-Osuna, F., Green-Ruiz, C., Sapozhnikov, D., RodríguezMeza, G., Godínez-Orta, L., 2001, Arsenic, antimony, selenium and other trace elements in sediments of the La Paz Lagoon, Peninsula of Baja California, Mexico: Marine Pollution Bulletin 42, 174-178.

Silverberg, N., Shumilin, E., Aguirre-Bahena, F., Rodríguez-Castañeda, A.P., Sapozhnikov, D., 2007, The impact of hurricanes on sedimenting particulate matter in the semi-arid Bahía de La Paz, Gulf of California: Continental Shelf Research 27, 2513-2522.

Manuscript received: February 05, 2009.

Corrected manuscript received: April 25, 2009.

Manuscript accepted: April 30, 2009. 